\title{
Antibacterial and antioxidative activities of licorice extracts fermented with Nuruk molds
}

\author{
Chan-Woo Kim ${ }^{1}$, Eun-Jeong Bae ${ }^{1}$, Ji-Eun Kang ${ }^{2}$, Han-Seok Choi ${ }^{3}$, \\ Seok-Tae Jeong ${ }^{1 *}$ \\ ${ }^{1}$ Fermented and Processed Food Science Division, National Institute of Agricultural Sciences, Jeonju 55365, Korea \\ ${ }^{2}$ Food and nutrition Division, National Institute of Agricultural Sciences, Jeonju 55365, Korea \\ ${ }^{3}$ Agriculture and Fisheries Processing Department, Korea National College of Agriculture and Fisheries, Jeonju 54874, Korea
}

\section{누룩곰팡이를 처리한 감초 발효 추출물의 항균 효과 및 항산화 활성}

\author{
김찬우 ${ }^{1} \cdot$ 배은정 ${ }^{1} \cdot$ 강지은 $^{2} \cdot$ 최한석 $^{3} \cdot$ 정석태 $^{1 *}$ \\ ${ }^{1}$ 국립농업과학원 발효가공식품과, ${ }^{2}$ 국립농업과학원 식생활영양과, \\ 3 한국농수산대학 농수산가공학과
}

\begin{abstract}
In this study, we investigated the antibacterial and antioxidative activities of fermented licorice extracts. Aspergillus luchuensis and Aspergillus oryzae were used for licorice, fermentation. The fermentation process was carried out at $35^{\circ} \mathrm{C}$, for 7 days. $\beta$-Glucosidase activity of koji made by $A$. luchuensis was $96.74 \mathrm{U} / \mathrm{g}$, which was higher than that of $A$. oryzae $(14.36 \mathrm{U} / \mathrm{g})$. Liquiritin content in licorice fermented with $A$. luchuensis and $A$. oryzae respectively decreased to $90.42 \mathrm{mg} / \mathrm{L}$ and $43.93 \mathrm{mg} / \mathrm{L}$, while that of liquiritigenin increased to $1,403.49 \mathrm{mg} / \mathrm{L}$ and $1,033.63$ $\mathrm{mg} / \mathrm{L}$. Antibacterial activity of liquiritigenin extract was higher than that of liquiritin. Licorice fermented with $A$. luchuensis showed stronger antibacterial activities $(11.5-14.5 \mathrm{~mm})$ than that fermented with $A$. oryzae (10.0-11.5 mm). DPPH radical-scavenging activity of a licorice fermented with $A$. luchuensis, in $A$. oryzae, and control was 65.35, 43.13, and $25.21 \%$, respectively. The highest ascorbic acid (AA) equivalent antioxidant capacity (AEAC) value (92.22 $\mathrm{mg} \mathrm{AA} \mathrm{eq/g)}$ ) was obtained for licorice fermented with $A$. luchuensis (control $=2.88 \mathrm{mg} \mathrm{AA} \mathrm{eq} / \mathrm{g}$ ). The results showed that fermented licorice extracts contain antibacterial and antioxidant components. Thus, fermented licorice extracts are useful for fermented foods that are difficult to preserve because of lactic acid bacteria.
\end{abstract}

Key words : antibacterial activity, antioxidant activity, fermentation, licorice

\section{서 론}

콩과에 속하는 다년생 초본 식물인 감초(Licorice, Glycyrrhizae radix)는 단맛, 쓴맛의 완화, 무독성 등 약제 외에도 식품 산업에 광범위하게 이용되어 왔다 $(1,2)$. 천연 의 감초는 여러 flavonoid로 구성되어 있는데, 사포닌 계통

*Corresponding author. E-mail : jst@korea.kr

Phone : 82-63-238-3615, Fax : 82-63-238-3843

Received 21 September 2018; Revised 7 November 2018; Accepted 23 November 2018.

Copyright (c) The Korean Society of Food Preservation. All rights reserved.
의 감미성분인 glycyrrhizin은 현재 감초의 지표성분으로써 $2.0 \%$ 이상을 함유하도록 규정되어 있다. 1 분자의 glycyrrhetinic acid와 2분자의 glucuronic acid로 이루어져 있으며, 설탕의 약 200-300배의 단맛으로 천연 감미료로 활용되며 항염증, 항바이러스 등에 효과적인 것으로 알려 져 있다(3-5). 감초의 주요 성분으로 triterpenoid saponin 계 통인 glycyrrhizin(glycyrrhizic acid)과 glycyrrhizinate, flavonoid 계통인 liquiritin, iso-liquiritin, apioliquiritin, liquiritigenin, glycyrol, glycyrin, licoricidin 및 licoricone, lycyrrhizin, glycyrrhetinic acid 등의 terpenoid가 알려져 있다 (6-7). Flavonoid계 지표물질인 liquiritin에서 당이 분리된 liquiritigenin은 냉장식품에서 생육 가능한 저온성균에 대한 
살균효과가 확인되었고(8), 일부 항산화 및 항균 효과가 있는 것으로 보고되었다(9). 또한 식물과 미생물에서 유래 된 조효소액으로 감초를 발효시켜 fibroblast 콜라겐 생성능 과 유용성분인 liquiritigenin의 함량을 증가시키는 연구도 수행되었고(10-12), 최근에는 세균, 효모, 곰팡이 등 다양한 균주를 활용한 발효기술을 통해 생리활성 효과가 증가하거 나 유익한 발효산물을 생성하는 것으로 알려져 있다(13).

한편, 우리나라의 전통 발효식품인 막걸리와 김치는 발 효 및 숙성과정 중에 미생물의 생육이 지나치면 산패되어 과도한 신맛이 생성되어 품질이 저하되는 문제점이 있다 (14). 품질에 영향을 미치는 미생물은 주로 젖산균으로 Lactobacillus, Leuconostoc, Enterococcus, Pediococcus속 등 이 분포한다(15-18). 이러한 미생물을 제어하기 위해 가열 살균방법이 일반적으로 이용되고 있지만 쓴맛의 발현, 가 열취 생성, 변색 등의 물리적 성상 변화를 일으켜 상품성을 저하시키는 문제점이 보고되었다(19). 이러한 문제점을 방 지하기 위해 저온 살균(20), 초고압 처리(21), 보존제 첨가 $(22,23)$, 감마선 조사(24) 등의 연구가 수행되었지만, 소비 자들의 식품첨가물에 대한 부정적인 인식이 증가하고 실제 산업현장에 적용하기 어려운 문제가 있다. 최근에는 다양 한 기능성 물질을 함유한 감초를 이용하여 식품의 저장성 및 기능성을 향상시키려는 연구가 수행되었는데, 열처리에 따른 감초 추출물의 항산화 활성(25), 감초와 강황 추출물을 첨가한 식빵(26), 소시지(27)의 저장성 및 기능성 향상에 관한 연구가 보고되었다.

본 연구에서는 감초를 활용한 천연물 소재 개발에 관한 연구의 일환으로 시중에 판매하는 누룩균(황국, 백국)을 감초에 직접 접종하여 발효함으로써 주요성분 중 하나인 liquiritigenin의 함량이 증가하는 것을 확인하였고, 유용 물 질이 증가된 감초 발효 추출물의 항균 효과와 항산화 활성 등을 살펴보았다.

\section{재료 및 방법}

\section{실험재료 및 시약}

본 실험에 사용한 감초(Glycyrrhiza uralensis)는 충북 제 천에서 건조된 국내산을 구입하여 분말화한 후 발효 추출용 시료로 사용하였다. 에탄올, DMSO 등 각종 용매는 시판 특급 시약을 사용하였다. 감초 성분의 항균 활성물질로 사 용된 liquiritin과 liquiritigenin은 Sigma Aldrich(St. Louis, $\mathrm{MO}, \mathrm{USA}$ )에서 구입하여 사용하였다.

\section{사용균주}

항균성 실험에 사용한 균주는 젖산균 6종이며, Lactobacillus brevis KACC 10553, L. paracasei KACC 12361, L. plantarum KACC 12404, L. casei KACC 12413,
Leuconostoc citreum KACC 11860, Pediococcus pentosaceus KACC 12311을 국립농업 과학원 농업미생물은행(Korean Agricultural Culture Collection)에서 분양 후 각 균주의 특성 에 맞는 성장 최적 조건 및 배지에서 배양하여 실험에 사용 하였다.

\section{감초 발효 추출물 제조}

감초 분말의 수분함량을 $40 \%$ 로 조정하여 $250 \mathrm{~mL}$ 삼각플 라스크에 $10 \mathrm{~g}$ 담아 $121^{\circ} \mathrm{C}$ 에서 15 분간 고압증자한 후 시중 에 판매하는 누룩균(황국: Aspergillus oryzae, 백국: Aspergillus luchuensis 충무발효, Ulsan, Korea)을 감초 무게 에 대하여 $0.1 \%(\mathrm{w} / \mathrm{w})$ 접종하고 $35^{\circ} \mathrm{C}$ 에서 7 일 동안 발효하 였다. $\operatorname{Kim}(28)$ 연구에서 추출 용매는 극성이 높은 유기용매 에서 항균, 항산화 활성이 높게 나타났으며 감초를 추출할 때 온도와 시간은 큰 영향을 주지 않기 때문에, $85 \%$ methanol과 dimethyl sulfoxide를 각각 $100 \mathrm{~mL}$ 넣고 상온에 서 5 시간 추출한 다음 거즈로 걸러 $12,000 \mathrm{rpm}$ 에서 15 분간 원심분리한 상등액을 시료로 사용하였다. 대조구는 누룩균 을 처리하지 않은 감초를 동일 조건에서 추출하여 사용하 였다.

\section{$\beta-$ Glucosidase 활성 측정}

베타글루코시다아제( $\beta$-glucosidase) 활성을 측정하기 위 하여 $1 \mathrm{mM}$ p-nitrophenol- $\beta$-D-glucoside(PNPG) $0.5 \mathrm{~mL}$ 를 $37^{\circ} \mathrm{C}$ 에서 5 분간 예열한 후 효소액 $50 \mu \mathrm{L}$ 를 첨가한다. $37^{\circ} \mathrm{C}$ 에서 10 분간 반응시킨 다음 $200 \mathrm{mM} \mathrm{Na}_{2} \mathrm{CO}_{3}$ 용액 $1 \mathrm{~mL}$ 를 가하여 반응을 정지한다. $410 \mathrm{~nm}$ 에서 흡광도를 측정하여 유리된 p-nitrophenol을 정량한다. $\beta$-Glucosidase 활성은 $\mathrm{PNPG}$ 에서 $37^{\circ} \mathrm{C}, 1$ 분 동안 $1 \mathrm{nmol}$ 의 p-nitrophenol을 만드는 역가를 1 unit으로 한다. 다음 식에 의해서 효소활성을 구한다.

$$
\text { 활성 }(\mathrm{U} / \mathrm{g} \mathrm{db})=\frac{\Delta \mathrm{OD}}{0.0184} \times \frac{1}{10} \times \frac{1.55}{0.5} \times \frac{50}{10} \times \frac{1}{(1-\text { 수분 })}
$$

\section{Liquiritin 및 liquiritigenin 함량 분석}

감초의 주요 성분인 liquiritin, liquiritigenin의 함량을 확 인하기 위해 감초 발효 추출물을 $0.2 \mu \mathrm{m}$ syringe filter(Millipore Co., Cork, Ireland)로 여과하였다. 분석은 HPLC(Alliance e2695, Waters Co., Milford, MA, USA)를 이용하였다. Column은 YMC-Pack Pro $\mathrm{C}_{18} \mathrm{RS}(4.6 \times 250 \mathrm{~mm}$, I.d. $5 \mu \mathrm{m}$, YMC Co., Kyoto, Japan)를 사용하였고, column oven의 온도는 $30^{\circ} \mathrm{C}$, flow rate는 $1.0 \mathrm{~mL} / \mathrm{min}$, injection volume은 $10 \mu \mathrm{L}$, 검출파장은 $254 \mathrm{~nm}$ 로 하였다. 이동상은 $0.025 \%$ formic acid와 acetonitrile 용액을 gradient하여 사용 하였다.

\section{항균 활성 시험}

감초 발효 추출물의 항균 활성 시험은 paper disk agar 
diffusion법(29)에 따라 실험용 균주의 slant로부터 각 균주 를 2백금이씩 취해 멸균한 $50 \mathrm{~mL} \mathrm{MRS}$ broth(Difco)에 접종 하여 $30^{\circ} \mathrm{C}$ 에서 24 시간 동안 전배양하였다. 균주가 배양된 배지를 MRS agar(Difco) $500 \mathrm{~mL}$ 에 각각 혼합하였다. 이 혼합액을 petri $\operatorname{dish}(87 \times 15 \mathrm{~mm})$ 에 $10 \mathrm{~mL}$ 씩 부어 평판배지 를 만들어 항균 활성 실험용 plate를 만들었다. 항균 활성 확인 실험을 위해 멸균된 $8 \mathrm{~mm}$ paper disc(Toyo Roshi Kaisha, Ltd., Tokyo, Japan)를 실험용 plate 표면 위에 올려놓 고 항균 활성을 확인하고자 하는 시험용액을 $40 \mathrm{uL}$ 흡수시 켜 $30^{\circ} \mathrm{C}$ incubator에서 24-48시간 동안 배양한 후 disk 주위 의 생육저해환 생성유무로 항균력을 측정하였다.

\section{1,1-Diphenyl-2-picryl hydrazyl(DPPH)에 의한 전자공여능 측정}

감초 발효 추출물의 1,1-diphenyl-2-picryl hydrazyl(DPPH) 에 의한 전자공여능(electron donating ability, $\mathrm{EDA}$ )은 Choi 등(30)의 방법에 따라 측정하였다. 즉, $0.2 \mathrm{mM} \mathrm{DPPH}$ 용액 (ethanolic solution) $0.8 \mathrm{~mL}$ 에 시료 $0.2 \mathrm{~mL}$ 를 첨가한 후 실온 에서 30 분 방치하여 $520 \mathrm{~nm}$ 에서 흡광도 감소치를 측정하였 다. 이 때 전자공여능은 시료 첨가구와 비첨가구의 흡광도 차이를 백분율(\%)로 나타내었다.

\section{총 항산화력 측정}

총 항산화력은 $\mathrm{ABTS}^{++}$cation decolorization assay방법 (31)에 의하여 측정하였다. 2,2'-Azino-bis-(3-ethylbenzothiazoline6-sulfonic acid)(ABTS) $7.4 \mathrm{mM}$ 과 potassium persulphate 2.6 $\mathrm{mM}$ 을 하루 동안 암소에 방치하여 $\mathrm{ABTS}^{+}$양이온을 형성 시킨 후 이 용액을 $735 \mathrm{~nm}$ 에서 흡광도 값이 1.4-1.5가 되도 록 몰 흡광계수 $\left(\varepsilon=3.6 \times 104 \mathrm{M}^{-1} \mathrm{~cm}^{-1}\right)$ 를 이용하여 메탄올로 희석하였다. 희석된 $\mathrm{ABTS}^{++}$용액 $1 \mathrm{~mL}$ 에 추출액 $50 \mu \mathrm{L}$ 를 가하여 흡광도의 변화를 정확히 60 분 후에 측정하였으며, 표준물질로서 L-ascorbic acid를 동량 첨가하였다. 총 항산화 력은 아래의 식으로 계산하였다.

$\operatorname{AEAC}(\mathrm{mg} \mathrm{AA}$ eq $)=\frac{\Delta \mathrm{A}}{\Delta \mathrm{A}_{\mathrm{aa}}} \times \mathrm{C}_{\mathrm{aa}} \times \mathrm{V} \times \frac{100}{\mathrm{~W}}$

AEAC : Ascorbic acid equivalent antioxidant activity $\triangle \mathrm{A}$ : 추출물을 넣었을 때의 $\mathrm{OD}$ 의 변화

$\Delta \mathrm{A}_{\mathrm{aa}}$ : $\mathrm{AA}$ std. soln.이 추출물 대신 동량 들어갔을 때의 $\mathrm{OD}$ 변화

$\mathrm{C}_{\mathrm{aa}}$ : $\mathrm{AA}$ std. soln.의 농도 $(\mathrm{mg} / \mathrm{mL})$

$\mathrm{V}$ : 추출물의 정용부피 $(\mathrm{mL})$

$\mathrm{W}$ : sample homogenate의 weight $(\mathrm{g})$

\section{통계분석}

각 분석항목에 대하여 3회 반복 측정하여 얻은 결과는
SPSS 12.0 통계 프로그램을 이용하여 평균과 표준편차를 구하였고, 독립표본 t-test 및 Ducan의 다중검정을 실시하여 유의성을 검증하였다(32).

\section{결과 및 고찰}

\section{$\beta$-Glucosidase 활성}

쌀알누룩을 만들 때 주로 사용하는 $A$ luchuensis와 $A$ oryzae를 감초에 직접 접종하여 발효함으로써 감초의 flavonoid 배당체인 liquiritin에서 당이 분리된 활성형 무배 당체인 liquiritigenin을 얻을 수 있다. 술을 만들기 위해 누룩 제조 시 사용되는 균주들은 각각의 특성이 있는데, Aspergillus속은 증자한 쌀에서 생육력이 높으며 강력한 당 화효소를 생성하는 것으로 알려져 있다(33). 상업적으로 많이 사용되는 $A$ luchuensis와 $A$ oryzae를 감초에 접종하기 위해 먼저 이 균주들의 $\beta$-glucosidase 활성을 측정한 결과 (Table 1), 백국균으로 제조한 쌀알누룩이 $96.74 \mathrm{U} / \mathrm{g}$ 으로 황국균 $14.36 \mathrm{U} / \mathrm{g}$ 에 비해 6.7 배 높게 나타났으며, 이는 $A$ luchuensis가 다른 균주에 비해 내산성 당화 amylase와 maltase 활성이 높다는 Lee 등(34)의 결과와 비슷하였다. 시중에 판매하는 종국 외 여러 균주로 누룩을 만들어서 $\beta$-glucosidase 활성을 측정한 결과(data not shown), 황국균 은 9.02-24.49 U/g, 백국균과 흑국균은 88.08-103.82 U/g으 로 나타났다. 따라서 감초 성분 중 당이 분리된 활성형 무배 당체를 증가시키고 적용하기 위해서는 시중에 판매하는 황국균보다 백국균으로 발효하는 것이 유리할 것으로 생각 된다.

Table 1. $\beta$-Glucosidase activity of rice Nuruk fermented with $A$ oryzae and $A$ luchensis

(unit/g, dry base)

\begin{tabular}{cc}
\hline & $\beta$-Glucosidas activity \\
\hline YN (Aspergillus oryzae CF1003) & $14.36 \pm 0.53^{1)}$ \\
WN (Aspergillus luchensis CF1005) & $96.74 \pm 7.86^{* 2)}$ \\
\hline
\end{tabular}

${ }^{1)}$ Values are mean \pm SE. Values are mean of triplicates.

${ }^{2)} \mathrm{p}<0.001$

\section{Liquiritin 및 liquiritigenin 함량}

시판 누룩균을 접종한 감초 발효 추출물의 liquiritin과 liquiritigenin의 함량 변화를 Table 2에 나타내었다. 발효를 하지 않은 대조구인 감초 추출물의 분석결과, liquiritin은 $2,468.67 \mathrm{mg} / \mathrm{L}$, liquiritigenin은 $254.23 \mathrm{mg} / \mathrm{L}$ 로 확인되었다. 백국균과 황국균을 접종해 발효한 감초는 배당체의 당이 가수분해 되면서 liquiritin 함량이 각각 $90.42 \mathrm{mg} / \mathrm{L}, 43.93$ $\mathrm{mg} / \mathrm{L}$ 로 감소한 반면, 아글리콘 형태인 liquiritigenin은 $1,403.49 \mathrm{mg} / \mathrm{L}, 1,033.63 \mathrm{mg} / \mathrm{L}$ 로 증가하였다. $\mathrm{Kim}$ 등(35)의 
연구에서 배당체는 생물전환과 효소 등에 의해 당이 가수분 해될 수 있으며 이렇게 생산된 아글리콘 형태는 체내 흡수 와 약리활성이 배당체보다 우수한 것으로 보고되어, 누룩 균을 활용해 감초를 발효시키는 것이 생리활성 면에서 대조 구보다 유리할 것으로 생각된다. 한편, 앞에서 백국균으로 제조한 쌀알누룩의 $\beta$-glucosidase 활성이 황국균보다 6.7배 높았으나, liquiritigenin의 함량은 1.4 배 차이만 발생했다. 이는 본 실험에서 발효기간을 7일로 고정하였는데, 이 기간 동안 누룩균에 의한 당의 가수분해가 충분히 이루어져 효소 활성이 영향을 적게 미친 것으로 사료되며, 추후 효소 활성 에 따른 감초의 최적 발효조건과 관련된 연구가 필요할 것으로 보인다. 또한 발효 전 감초의 수분함량을 $70 \%$ 로 설정할 경우 liquiritigenin의 함량이 $40 \%$ 보다 3.9-4.1배 감소 되어, 발효 전 수분함량이 너무 많을 경우 효소 활성 형성에 부정적인 영향을 미치는 것으로 사료된다.

Table 2. Contents of liquiritin and liquiritigenin in fermented licorice extracts

\begin{tabular}{ccc} 
& & (unit: $\mathrm{mg} / \mathrm{L}$, dry base) \\
\hline Control & $\left.2,468.67 \pm 121.29^{1 / \mathrm{a} 2}\right)$ & $254.23 \pm 28.81^{\mathrm{c}}$ \\
$\begin{array}{c}\text { Fermented licorice } \\
(A \text { luchuensis })\end{array}$ & $90.42 \pm 2.49^{\mathrm{b}}$ & $1,403.49 \pm 99.31^{\mathrm{a}}$ \\
$\begin{array}{c}\text { Fermented licorice } \\
(A \text { oryzae })\end{array}$ & $43.93 \pm 6.07^{\mathrm{c}}$ & $1,033.63 \pm 68.66^{\mathrm{b}}$ \\
\hline
\end{tabular}

${ }^{1)}$ Values are mean \pm SE. Values are mean of triplicates.

${ }^{2)}$ Means with the different superscripts in a column are significantly different $(\mathrm{p}<0.05)$.

\section{항균 활성}

감초의 구성성분인 liquiritin과 liquiritigenin의 젖산균 6 종에 대한 항균 활성을 검정한 결과를 Table 3에 나타내었 다. 아글리콘 형태인 liquiritigenin이 liquiritin 보다 전반적 으로 더 높은 항균 활성을 보였으며, 특히 $1 \%$ 처리 시 $L$. paracasei, P. pentosaceus 균에 대하여 각각 $21.5,18.5 \mathrm{~mm}$ 의 clear zone 형성으로 강한 항균 활성을 나타내었다. 표준품 의 농도가 증가할수록 항균 활성이 증가하는 경향을 보였으 나, L. casei 균에 대해서는 비슷한 수준으로 확인되었다. $\mathrm{Kim}$ 등(35)의 선행연구에서 아글리콘 형태가 배당체보다 생리활성 면에서 우수한 것으로 보고되어, 본 연구결과와 비슷하게 나타났다. 감초 발효 추출물의 젖산균 6 종에 대한 항균 활성을 조사한 결과는 Table 4 와 같다. 백국균으로 발효한 감초 추출물은 모든 균에서 가장 높은 clear zone을 보였으며 $(11.5-14.5 \mathrm{~mm})$, 특히 Leu. citreum에 대해 높은 항균성을 보였다. 황국균으로 발효한 감초 추출물의 경우, P. pentosaceus에 대해서는 항균력이 없었으며, 10.0-11.5 $\mathrm{mm}$ 로 백국균에 비해 항균 활성이 비교적 낮게 확인되었다. 결론적으로 백국균으로 발효한 감초에서 liquiritigenin과 같 은 아글리콘 형태의 물질들이 증가하면서 젖산균의 항균 활성에 영향을 미친 것으로 사료된다.

Table 4. Antibacterial activities of fermented licorice extracts against lactic acid bacteria

\begin{tabular}{cccc}
\hline \multirow{2}{*}{ Strain } & \multicolumn{3}{c}{ Clear zone on plate $(\mathrm{mm})$} \\
\cline { 2 - 4 } & \begin{tabular}{c} 
Control \\
\cline { 2 - 3 }
\end{tabular} & $\begin{array}{c}\text { Fermented licorice } \\
\text { (A luchuensis })\end{array}$ & $\begin{array}{c}\text { Fermented licorice } \\
(\text { A oryzae })\end{array}$ \\
\hline L. brevis & $-1)$ & $++(12.0)$ & $+(10.0)$ \\
L. paracasei & - & $++(11.5)$ & $+(10.0)$ \\
L. plantarum & - & $+++(12.5)$ & $++(11.0)$ \\
L. casei & - & $++(13.5)$ & $++(11.5)$ \\
Leu. citreum & - & $+++(14.5)$ & $++(11.5)$ \\
P. pentosaceus & - & $++(12.0)$ & - \\
\hline
\end{tabular}

1)-, no inhibition $(<8 \mathrm{~mm}) ;+$, slight inhibition $(8-10 \mathrm{~mm}) ;++$, moderate inhibition $(10-12 \mathrm{~mm}) ;+++$, strong inhibition $(>12 \mathrm{~mm})$.

\section{항산화 활성}

인체 내의 과도한 free radical은 지질, 단백질 등을 산화하 여 세포의 항상성을 파괴하고 노화를 촉진시켜 질병의 원인

Table 3. Antibacterial activities of liquiritin and liquiritigenin against lactic acid bacteria

\begin{tabular}{|c|c|c|c|c|c|c|c|c|c|c|c|}
\hline \multirow{4}{*}{ Strain } & \multicolumn{11}{|c|}{ Clear zone on plate $(\mathrm{mm})$} \\
\hline & \multirow{3}{*}{$\begin{array}{l}\text { Control } \\
\text { DMSO }\end{array}$} & \multicolumn{10}{|c|}{ Concentration of standard solution $(\mathrm{mg} / \mathrm{L})$} \\
\hline & & \multicolumn{5}{|c|}{ Liquiritin } & \multicolumn{5}{|c|}{ Liquiritigenin } \\
\hline & & 625 & 1,250 & 2,500 & 5,000 & 10,000 & 625 & 1,250 & 2,500 & 5,000 & 10,000 \\
\hline L brevis & 1) & $++(12.0)$ & $++(11.5)$ & $++(12.0)$ & $++(11.5)$ & $++(12.0)$ & $++(11.0)$ & $++(11.0)$ & $++(11.5)$ & $+++(12.5)$ & $+++(16.0)$ \\
\hline L. paracasei & - & $+++(13.0)$ & $+++(12.5)$ & $+++(13.5)$ & $+++(13.5)$ & $+++(14.0)$ & $++(12.0)$ & $++(12.0)$ & $+++(12.5)$ & $+++(18.5)$ & $+++(21.5)$ \\
\hline L. plantarum & - & $++(11.0)$ & $++(11.5)$ & $++(11.0)$ & $++(11.0)$ & $++(11.5)$ & $++(10.5)$ & $++(12.0)$ & $++(11.0)$ & $+++(13.0)$ & $+++(16.0)$ \\
\hline L. casei & - & $++(10.0)$ & $++(10.0)$ & $++(11.0)$ & $++(11.5)$ & $++(12.0)$ & $++(11.0)$ & $++(11.5)$ & $++(11.5)$ & $++(12.0)$ & $++(12.5)$ \\
\hline Leu. citreum & - & $++(11.0)$ & $++(11.5)$ & $++(11.5)$ & $++(11.0)$ & $+++(12.5)$ & $++(11.0)$ & $++(11.5)$ & $+++(13.0)$ & $+++(15.5)$ & $+++(16.0)$ \\
\hline P. pentosaceus & - & $++(12.0)$ & $+++(13.0)$ & $+++(13.0)$ & $+++(13.0)$ & $+++(13.5)$ & $++(12.0)$ & $++(12.0)$ & $+++(14.0)$ & $+++(17.0)$ & $+++(18.5)$ \\
\hline
\end{tabular}

\footnotetext{
${ }^{1)}$-, no inhibition $(<8 \mathrm{~mm})$; +, slight inhibition $(8-10 \mathrm{~mm})$; ++, moderate inhibition $(10-12 \mathrm{~mm})$; +++ , strong inhibition $(>12 \mathrm{~mm})$.
} 
Table 5. DPPH radical scavenging activity of fermented licorice extracts

\begin{tabular}{|c|c|c|c|}
\hline \multirow{2}{*}{$\begin{array}{l}\text { DPPH radical scavenging } \\
\text { activity }(\%)\end{array}$} & Cont & $\begin{array}{l}\text { Fermented licorice } \\
\text { (A luchuensis) }\end{array}$ & $\begin{array}{l}\text { Fermented licorice } \\
\text { ( } A \text { oryzae })\end{array}$ \\
\hline & & $65.35 \pm 1.19^{\mathrm{a}}$ & $43.13 \pm 0.42^{b}$ \\
\hline
\end{tabular}

${ }^{1)}$ Values are mean \pm SE. Values are mean of triplicates.

${ }^{2}$ Means with the different superscripts in a row are significantly different $(p<0.05)$.

이 되며, 이러한 free radical을 제거할 수 있는 천연 항산화 물질에 대한 연구가 계속적으로 수행되고 있다. 감초 발효 추출물의 DPPH 라디칼 소거능을 측정한 결과는 Table 5에 서 보는 바와 같다. 백국균으로 발효한 감초 추출물에서 $65.35 \%$ 로 가장 높게 나타났고 황국균에서도 $43.13 \%$ 로 대 조구에 비해 각각 $2.6,1.7$ 배 증가하여, $\mathrm{Kim}$ 등(9)의 연구에 서 된장으로부터 분리한 균주 유래 조효소액 처리 시 항산 화 활성이 2 배 정도 증가되었다는 결과와 일치하였다. Kim 등(36)의 연구에서는 한국 약용 및 식물자원의 항산화력을 측정한 결과 대부분 식물자원의 활성이 $20 \%$ 미만으로 보고 하였는데, 이러한 결과와 비교해 볼 때 대조구인 감초 추출 물 자체의 항산화력도 $25.21 \%$ 로 다른 식물자원에 비해 높 게 나타났으며, 특히 누룩균을 접종하여 발효했을 때 매우 높은 전자공여능을 가지는 것으로 확인되었다. 총 항산화 력(AEAC, ascorbic acid equivalent antioxidant activity)을 측정한 결과는 Table 6에서 보는 바와 같이 백국균으로 발효한 감초 추출물에서 $92.22 \mathrm{mg} \mathrm{AA} \mathrm{eq/100} \mathrm{g으로} \mathrm{가장}$ 높게 나타나 DPPH 라디컬 소거능 결과와 일치하며, 이는 배당체의 당이 분해되고 아글리콘 형태가 증가하면서 전자 공여능과 총 항산화력에 영향을 미친 것으로 생각된다. $\mathrm{DPPH}$ 와 $\mathrm{ABTS}$ 실험 결과의 차이는 $\mathrm{DPPH}$ 는 안정한 유리 라디칼이고 $\mathrm{ABTS}$ 는 양이온 라디칼이라는 차이와, DPPH 는 주로 소수성 물질의 항산화능을 측정하는데 $\mathrm{ABTS}$ 는 친수성과 소수성 물질의 항산화능을 다 측정할 수 있는 차이 등에 기인한다(37,38). 본 실험에 사용된 시료에는 다 양한 생리활성 물질들이 혼재되어 있어 이들의 분리, 정제 및 검정 연구는 앞으로 필요하며 산업에 활용할 수 있는 소재화 기술 개발도 필요할 것으로 생각된다.

Table 6. Total antioxidant activity (AEAC) of fermented licorice extracts

\begin{tabular}{|c|c|c|c|}
\hline \multirow{2}{*}{$\begin{array}{c}\text { AEAC } \\
(\mathrm{mg} \text { AA eq/100 g) }\end{array}$} & Control & $\begin{array}{l}\text { Fermented licorice } \\
\text { (A luchuensis) }\end{array}$ & $\begin{array}{l}\text { Fermented licorice } \\
\text { ( } A \text { oryzae })\end{array}$ \\
\hline & $2.88 \pm 0.10^{1) b 2}$ & $92.22 \pm 14.96^{\mathrm{a}}$ & $0.69 \pm 0.97^{c}$ \\
\hline
\end{tabular}

${ }^{1)}$ Values are mean $\pm \mathrm{SE}$. Values are mean of triplicates.

${ }^{2}$ Means with the different superscripts in a row are significantly different $(p<0.05)$.

\section{요 약}

본 연구에서는 시중에 판매하는 누룩균을 감초에 직접
접종하여 발효 과정을 통해 감초의 주요성분 중 하나인 liquiritigenin의 함량을 증가시키며, 이에 따른 항균 및 항산 화 효과를 알아보고자 하였다. 쌀알누룩을 만들 때 주로 사용하는 $A$ luchuensis와 $A$ oryzae를 감초 발효에 사용하면 flavonoid 배당체인 liquiritin에서 당이 분리되어 활성화된 무배당체인 liguiritigenin을 얻을 수 있다. 백국균으로 제조 한 쌀알누룩의 $\beta$-glucosidase이 $96.74 \mathrm{U} / \mathrm{g}$ 으로 황국균 14.36 $\mathrm{U} / \mathrm{g}$ 에 비해 6.7배 높게 나타났다. 발효를 하지 않은 대조구 인 감초 추출물의 분석결과, liquiritin은 $2,468.67 \mathrm{mg} / \mathrm{L}$, liquiritigenin은 $254.23 \mathrm{mg} / \mathrm{L}$ 로 확인되었다. 백국균과 황국 균을 접종해 발효한 감초는 배당체의 당이 가수분해 되면서 liquiritin 함량이 각각 $90.42 \mathrm{mg} / \mathrm{L}, 43.93 \mathrm{mg} / \mathrm{L}$ 로 감소하였고 아글리콘 형태인 liquiritigenin은 $1,403.49 \mathrm{mg} / \mathrm{L}, 1,033.63$ $\mathrm{mg} / \mathrm{L}$ 로 증가하였다. 감초의 구성성분인 liquiritin과 liquiritigenin의 젖산균 6 종에 대한 항균 활성을 검정한 결 과, liquiritigenin이 liquiritin 보다 전반적으로 더 높은 항균 활성을 나타냈으며, 특히 $1 \%$ 처리 시 L. paracasei, $P$. pentosaceus 균에 대하여 각각 $21.5,18.5 \mathrm{~mm}$ 의 clear zone 형성으로 강한 항균 활성을 나타내었다. 백국균으로 발효 한 감초 추출물은 모든 균에서 가장 높은 clear zone을 보였 으며(11.5-14.5 mm), 특히 Leu. citreum에 대해 높은 항균성 을 보였다. 황국균으로 발효한 감초 추출물의 경우, $P$. pentosaceus에 대해서는 항균력이 없었으며, $10.0-11.5 \mathrm{~mm}$ 로 백국균에 비해 항균 활성이 비교적 낮게 확인되었다. $\mathrm{DPPH}$ 라디칼 소거능은 백국균으로 발효한 감초 추출물에 서 $65.35 \%$ 로 가장 높게 나타났으며, 황국균에서도 $43.13 \%$ 로 대조구에 비해 각각 $2.6,1.7$ 배 증가하였고, 총 항산화력 또한 백국균으로 발효한 감초 추출물에서 $92.22 \mathrm{mg} \mathrm{AA}$ $\mathrm{eq} / 100 \mathrm{~g}$ 으로 가장 높게 나타났다.

\section{감사의 글}

본 연구는 국립농업과학원 기관고유사업(과제번호: PJ01135302)의 지원에 의해 이루어진 것이며, 연구비 지원 에 감사드립니다.

\section{References}

1. Fukai T, Satoh K, Nomura T, Sakagami H (2003) Preliminary evaluation of antinephritis and radical scavenging activities of glabridin from Glycyrrhiza glabra. Fitoterapia, 74, 624-629

2. Kang MH, Park CG, Cha MS, Seong NS, Chung HK, Lee JB (2001) Component characteristics of each extract prepared by different extract methods from by-products 
of Glycyrrhiza uralensis. J Korean Soc Food Sci Nutr, 30, 138-142

3. Sohn EJ, Kang DG, Lee AS, Lee YM, Yin MH, Yeum KB, Noh SY, Lee HS (2003) Antioxidant activities of glycyrrhizin and its effect on renal expression of $\mathrm{Na}$, $\mathrm{K}$-ATPase in gentamicin-induced acute renal failure rats. Korean J Orient Physiol Pathol, 17, 542-548

4. Matsuia S, Matsumotoc $\mathrm{H}$, Sonodab $\mathrm{Y}$, Andob K, Aizu-Yokotab E, Satoc T, Kasaharab T (2004) Glycyrrhizin and related compounds down-regulate production of inflammatory chemokines IL-8 and eotaxin 1 in a human lung fibroblast cell line. Int Immunopharmacol, 4, 1633-1644

5. Wolkerstorfer A, Kurz H, Bachhofner N, Szolar OHJ (2009) Glycyrrhizin inhibits influenza a virus uptake into the cell. Antiviral Res, 83, 171-178

6. Fenwick GR, Lutomski J, Nieman C (1990) Liquorice, Glycyrrhiza glabra L.: Composition, uses and analysis. Food Chem, 38, 119-143

7. Hatano T, Kagawa H, Yasuhara T, Okuda T (1988) Two new flavonoids and other constituents in licorice root: their relative astringency and radical scavenging effects. Chem Pharm Bull, 36, 2090-2097

8. Ahn EY, Shin DH, Baek NI, Oh JA (1998) Isolation and identification of antimicrobial active substance from Glycyrrhiza uralensis FISCH. Korean J Food Sci Technol, 30, 680-687

9. Kim SI, Kim JE, So JH, Rhee IK, Chung SK, Lee KB, Yoo YC, Song KS (2004) Changes in liquiritigenin contents in licorice extract treated by the crude enzme extract from Aspergillus kawachii. Korean J Pharmacogn, 35, 309-314

10. Kiso Y, Tohkin M, Hikino H, Hattori M, Sakamoto T, Namba T (1984) Mechanism of antihepatotoxin activity of glycyrrhizin effect on free radical generation and lipid peroxidation. Planta Med, 50, 298-302

11. Um YR, Shim KS, Lee JH, Park HY, Ma JY (2009) Quantitative analysis of glycyrrhizic acid in fermented Glycyrrhizae radix by HPLC. Korean J Orient Med, 15, 85-89

12. Na IS, Park MJ, Noh CH, Min JW, Bang MH, Yang DC (2008) Production of flavonoid aglycone from Korean Glycyrrhizae radix by biofermentation process. Korean J Orient Physiol Pathol, 22, 569-574

13. Tsukahara M, Shinzato N, Tamaki Y, Namihira T, Matsui $\mathrm{T}$ (2009) Red yeast rice fermentation by selected Monascus sp. with deep-red color, lovastatin production but no citrinin, and effect of temperature-shift cultivation on lovastatin production. Appl Biochem Biotechnol, 158, 476-482

14. Park CH, Jung HK, Park HH, Hong JH (2007) Identification and fermentation characteristics of lactic acid bacteria isolated from Hahyangju nuruk Korean J Food Preserv, 14, 188-193

15. Jin J, Kim SY, Jin Q, Eom HJ, Han NS (2008) Diversity analysis of lactic acid bacteria in Takju Korean rice wine. Korean J Microbiol Biotechnol, 18, 1678-1682

16. Kim SY, Yoo KS, Kim JE, Kim JS, Jung JY, Jin Q, Eom HJ, Han NS (2010) Diversity Analysis of lactic acid bacteria in Korean rice wines by culture-independent method using PCR-denaturing gradient gel electrophoresis. Food Sci Biotechnol, 19, 749-755

17. Min JH, Nam YG, Ju JI, Jung JH, Lee JS, Kim HK (2012) Changes in yeast and bacterial flora during fermentation and storage of Gugija-Liriope tuber Makgeolli using PCR-DGGE. Korean J Microbial Biotechnol, 40, 111-116

18. Kim JY, Kim DH, Park PJ, Kang HI, Ryu EK, Kim SM (2011) Effects of storage temperature and time on the biogenic amine content and microflora in Korean turbid rice wine, Makgeolli. Food Chem, 128, 87-92

19. Lee GH (1994) The properties and new technologies of Korean medicinal wine and Takju. J Microbiol Biotechnol, 7, 4036-4046

20. Lee CH, Tae WT, Kim GM, Lee HD (1991) Studies on the pasteurization conditions of Takju. Korean J Food Sci Technol, 23, 44-51

21. Lim SB, Jwa MK, Mok CK, Park YS, Woo GJ (2004) Changes in microbial counts, enzyme activity and quality of foxtail millet takju treated with high hydrostatic pressure during storage. Korean J Food Sci Technol, 36, 233-238

22. Song MN (1985) Studies on the preservation of takjoo by the addition of egg white lysozyme. MS Thesis, Korea University, Korea

23. Yoo JY, Lee S (1997) Use of nisin for improved ethanol production Takju fermentation. Korean J Appl Microbiol Biotechnol, 25, 203-206

24. Chang AC (2003) The effects of gamma irradiation on rice wine maturation. Food Chem, 83, 323-327

25. Woo KS, Jang KI, Kim KY, Lee HB, Jeong HS (2006) Antioxidant activity of heat treated licorice (Glycyrrhiza uralensis Fisch) extracts. Korean J Food Sci Technol, $38,355-360$ 
26. Lee SY, Choi JS, Choi MO, Cho SH, Kim KBWR, Lee WH, Park SM, Ahn DH (2006) Effect of extract from Glycyrrhiza uralensis and Curcula longa on shelf-life and quality of bread. Korean J Food Sci Technol, 35, 912-918

27. Cho SH, Jung SA, Song EJ, Lee SY, Kim KBWR, Park JG, Park SM, Ahn DH (2006) Effect of improvement of storage properties and reducing of sodium nitrate by Glycyrthiza uralensis and Curcula longa in pork sausage. Korean J Food Sci Technol, 35, 997-1004

28. Kim SJ (2003) Optimization of extraction conditions for the antimicrobial and antioxidative materials from Glycyrrhiza glabra and investigation of its activity. MS Thesis, Andong University, Korea

29. Park UY, Chang DS, Cho HR (1992) Screening of antimicrobial activity for medicinal herb extracts (in Korean). J Korean Soc Food Sci Nutr, 21, 91-96

30. Choi Y, Kim MH, Shin JJ, Park JM, Lee J (2003) The antioxidant activities of the some commercial teas. Korean J Soc Food Sci Nutr, 32, 723-727

31. Dewanto V, Xianzhong W, Liu RH (2002) Processed sweet corn has higher antioxidant activity. J Agric Food Chem, 50, 4959-4964
32. Kim SC, Lim Johan (2010) Note on the equality of variances in two sample t-test. Korean J Statistical Soc, 17, 79-88

33. Kim HS, Hyun JS, Kim J, Ha HP, Yu DS (1997) Research trend of traditional Nuruk fungal. Korean J Microbiol Biotechnol, 10, 27-32

34. Lee TS, Choi JY (2005) Volatile flavor components in mash of Takju prepared by using Aspergillus kawachii Nuruks. Korean J Food Sci Technol, 37, 944-950

35. Kim MK, Lee JW, Lee KY, Yang DC (2005) Microbial conversion of major ginsenoside $\mathrm{Rb} 1$ to pharmaceutically active minor ginsenoside Rd. J Microbiol, 43, 5, 456-462

36. Kim YC, Chung SK (2002) Reactive oxygen radical species scavenging effects of Korean medicinal plant leaves. Food Sci Biotechnol, 11, 407-411

37. Yu L, Haley S, Perret J, Harris M, Wilson J, Qian M (2002) Free radical scavenging properties of wheat extracts. J Agric Food Chem, 50, 6, 1619-1624

38. Floegel A, Kim DO, Chung SJ, Koo SI, Chun OK (2011) Comparison of ABTS/DPPH assays to measure antioxidant capacity in popular antioxidant-rich US foods. J Food Compos Anal, 24, 1043-1048 